\title{
$0-11$
}

Stage IV 腎細胞癌における mass reductive surgery の意義

北里大学 1)、山近病院 2 )

岩村正嗣 1)、村本将俊 1 )、葛西 勲 2 )、頴川 晋 1 )、

内田豐昭 ${ }^{1}$ )、小柴 健 ${ }^{1}$ )

（目的）多発性転移を伴う腎細胞癌おける原発巣摘徐の是非については議論が多い。今 回、北里大学病院において経験した転移巣の完全切除不能な進行性堅細胞癌症例を用い， mass reductive surgery の意義について検討した。（対象と方法）1971年から1995年の25年 間に経験した腎細胞癌275例のうち、受診時に多発性転移を認めた症例74例（男性54例、 女性20例）を対象とし、堅摘出術の生命予後に与える影響をKaplan-Meier 法を用いて検討 し、generalized Wilcoxon 法にて検定した。（結果）対象の平均年齢は60.3歳で follow up 期間は 3-86 月であった。転移部位は単一臟器のみが29例、多喴器にわたるものが45 例であり、臓器別にみると肺38例、骨38例、肝13例、リンパ節22例であった。74例うち堅 摘出術は38例 (51.3\%) に対し施行された。手術群、非手術群、単一臟器転移群、多臟器 転移群に分け累積生存率を検討したところ4群間に有意差は認められなかった。また原発 巣切除に伴う転移巣の自然退縮は1例も経験しなっかた。（考察）切除不能な転移栄を有 する腎細胞癌において、原発巣摘出術は予後の改善に寄与しないもの之思われる。今後、 腎摘徐術が免疫療法の効果へ及ぼす影響についても検討を加える予定である。

\section{O-12 督瘭転移巣の発育速度に閉する検討}

\author{
横須賀共済 (1)、神奈川県立足柄上 2)、茅ヶ猗市立 ${ }^{3)}$ 、横浜市大4)、横浜船員(保険2) \\ 福田百邦 ${ }^{1)}$ 、三好康秀 ${ }^{1)}$ 、朝倉智行 ${ }^{1)}$ 、松崎純一 ${ }^{1)}$ 、里見佳昭 ${ }^{1)}$ 、 \\ 中橋 満 ${ }^{2)}$ 、仙賀 裕 $^{3)}$ 、岸田 健 ${ }^{4)}$ 、大古美治 ${ }^{5)}$
}

〔目的〕1）堅演転移巣の発育速度が転移果出現後の予後規定因子となり得るか、2) 同一症例で転移 歲器による発育速度の差が認められるかどうか、3）認められるとすれば、何らかの缄器特異性がある のかどうかを明らかにする事を目的とした。〔対象と方法〕横須賀共済病院において経臨した䟧癌症例 中、転移宩の発育速度を測定し得た65例を対象として検討した。発育速度の测定方法は、Collins ら、 およびGarlandらの方法に準じた。〔結果〕1)転移宩、特に肺転移巣の発育速度と転移出現後の生存 期間との間に、有意の相関関係を認めた。2）同一症例で転移臌器により、かなりの発育速度の差が認 められる症例が存在した。3）皮庙転移は発育速度が速く、リンパ節転移、留転移は発育速度が通い傾 向であった。また、骨転移は肺転移より、発育速度が速い症例が多かった。4)転移果の治療を行う上 で、各転移巣の発育速度を考肴し、きめ細かく治療方針を決定する事が重要であると考えられた。なお、 転移单の発育速度と他の予後規定因子との相関関係、転移䉾の発育速度からみた、転移巣手術の適応に ついても検討したので合わせて報告する予定である。 